\title{
OPTIMASI PCR (POLYMERASE CHAIN REACTION) UNTUK DETEKSI ENDOPARASIT YANG MENYERANG TELUR DAN LARVA IKAN TUNA SIRIP KUNING (Thunnus albacares)
}

\author{
Gusti Ngurah Permana, Jhon Harianto Hutapea, dan Haryanti \\ Balai Besar Riset Perikanan Budidaya Laut \\ Jl. Br. Gondol, Kec. Gerokgak, Kab. Buleleng, Kotak Pos 140, Singaraja-Bali 81101 \\ E-mail: gustipermana@gmail.com
}

(Naskah diterima: 3 Maret 2009; Disetujui publikasi: 15 Januari 2010)

\begin{abstract}
ABSTRAK
Endoparasit merupakan parasit yang menginfeksi dan terdapat di dalam tubuh inang, endoparasit ini telah menginfeksi telur dan larva ikan tuna sirip kuning. Tujuan dari penelitian adalah untuk mengetahui metode deteksi dan infeksi dari endoparasit ini secara molekuler dengan teknik PCR (Polymerase Chain Reaction). Telur dan larva yang terinfeksi dikumpulkan dari bak pemeliharaan untuk dianalisis. Sampel diekstraksi dengan menggunakan metode lysis bufer dan trizol. Hasil analisis menunjukkan lysis bufer memberikan pola pita yang lebih jelas dan bersih. Primer P2: 1322f (2F) CCGGAACTTTAGAGTATCGG; 1680r (2R) TCGGTTCAG ACTGA ACCAAG menghasilkan pola pita yang konsisten dan jelas dengan panjang fragmen $350 \mathrm{bp}$. Hal ini mengindikasikan bahwa endoparasit (Ichtyodinium chambelardi) menyerang telur ikan tuna di dalam bak terkontrol dan infeksinya terjadi adalah secara horisontal yang berasal dari air media pemeliharaan.
\end{abstract}

KATA KUNCl: endoparasit, deteksi, Polymerase Chain Reaction, tuna sirip kuning

ABSTRACT: Optimization of PCR (Polymerase Chain Reaction) method for detection of endoparasit in the egg and larvae of yellowfin tuna (Thunnus albacares). By: Gusti Ngurah Permana, Jhon Harianto Hutapea, and Haryanti

Endoparasite is a parasite that lives within the body of its host and it has been discovered infecting egg and larvae of yelowfin tuna in captivity. The aims of this experiment was to detect endoparasite in the egg and larvae of yellowfin tuna using PCR (Polymerase Chain Reaction) method. Infected eggs and larvae were taken from broodstock tank and extracted using lysis buffer and trizol method. The result showed that bands of sample extracted using lysis buffer method produced more sharp and clear band pattern compared to trizol method. Primer P2: $1322 f(2 F)$ CCGGAACTTTAGAGTATCGG; 1680r (2R) TCGGTTCAGACTGAACCAAG showed consistent band with fragment site of $350 \mathrm{bp}$. This experiment indicated that identical endoparasite (Ichtyodinium chambelardi) were found in egg and larvae of yellowfin tuna in captivity and the infection was suspected to come horizontaly from rearing water.

KEYWORDS: endoparasite, detection, Polymerase Chain Reaction, yellowfin tuna 


\section{PENDAHULUAN}

Perbenihan ikan tuna sirip kuning dalam bak terkontrol telah dirintis mulai tahun 2002 oleh Badan Riset Kelautan dan Perikanan yang dilaksanakan di Balai Besar Riset Perikanan Budidaya Laut (BBRPBL), Gondol-Bali yang bekerja sama dengan Overseas Fishery Cooperation Foundation (OFCF) Jepang. Ikan tuna yang dipelihara di dalam bak terkontrol dengan menggunakan induk yang ditangkap dari perairan Bali Utara telah berhasil memijah. Pemijahan pertama terjadi pada tanggal 25 Oktober 2004 selama 9 hari dan berhenti, kemudian bertelur kembali mulai tanggal 15 Agustus 2005 hampir setiap hari. Tingkat keberhasilan perbenihan ikan tuna ini masih sangat rendah, salah satu kendala yang dihadapi adalah infeksi endoparasit pada telur dan larva yang pertama kali diketahui terjadi pada tanggal 20 Oktober 2005. Beberapa peneliti melaporkan bahwa adanya endoparasit yang menyerang telur ikan antara lain pada ikan sardine (Holande, 1952; Collate et al., 1983; Ishimaru, 2005). Kasus yang sama juga ditemukan pada ikan tuna sirip biru (Thunnus thynus orientalis) yang menginfeksi telur ikan tuna di Kinki University Jepang, larva ikan cod (Gadus morhua) dan ikan turbot (Scopthalmus maximus) (Pedersen et al., 1994). Endoparasit yang menyerang teridentifikasi dari jenis Icthtyodinium chambelardi. Lebih lanjut Ishimaru (2004), menyatakan bahwa endoparasit tersebut menyerang telur ikan tuna sirip biru (Thunnus thynus orientalis) dan telah dilakukan identifikasi secara molekuler dengan target gen adalah 18S-rDNA dan teridentifikasi yaitu jenis Icthtyodinium chambelardi.

Tujuan dari penelitian ini adalah untuk mengidentifikasi endoparasit yang menyerang telur ikan tuna sirip kuning, $T$. albacares dengan menggunakan positif kontrol dari endoparasit tersebut dengan deteksi molekuler genetik menggunakan teknik PCR (Polymerase Chain Reaction) serta mengetahui pola infeksinya dari endoparasit tersebut pada bak terkontrol.

\section{BAHAN DAN METODE}

\section{Pengambilan Sampel}

Tahap pertama adalah mengumpulkan sampel telur dan larva ikan tuna sirip kuning yang sehat dan terinfeksi endoparasit yang diamati dengan menggunakan mikroskop. Perkembangan embrio pada saat pengambilan sampel adalah 32 sel dan larva pada hari ke-0 (d-0). Jumlah sampel telur dan larva yang dipergunakan untuk analisis masing-masing 50 ekor. Sampel telur diawetkan dengan menggunakan ethanol 95\% sedangkan sperma dan gonad diambil dari tiga induk yang mati di bak pemeliharaan induk dan disimpan pada suhu $-20^{\circ} \mathrm{C}$ sebelum dianalisis.

Pada tahap kedua dilakukan amplifikasi pada gonad (sel telur dan sperma) induk, pakan induk yaitu ikan layang (Decapterus macarellus) dan air media pemeliharaan serta sumber air laut dari filter pasir (sand filter) yang disaring sebanyak 200 L dengan menggunakan saringan 20 untuk mengetahui sumber dari endoparasit ini. Sampel pakan ikan tuna yaitu ikan layang yang digunakan adalah isi perutnya. Tujuan dari analisis ini adalah untuk mengetahui sumber infeksi dari endoparasit ini, secara vertikal dari induk atau secara horisontal dari air.

\section{Ekstraksi Genom DNA Endoparasit}

Proses ekstraksi genom DNA merupakan langkah yang sangat penting untuk menentukan hasil analisis. Ekstraksi DNA mengikuti metode Yuasa et al. (2006), menggunakan 2 metode yaitu metode trizol (Invitrogen-chloroform) dan lysis bufer (Invitrogen).

\section{Metode Ekstraksi dengan Trizol}

Sampel telur dan larva yang terinfeksi endoparasit dicuci terlebih dahulu dengan double distillited water $\left(\mathrm{dd}_{2} \mathrm{O}\right)$ untuk menghilangkan ethanolnya. Tambahkan 200 $\mu \mathrm{L}$ trizol dan gerus/hancurkan dengan pellet paste kemudian tambahkan lagi $700 \mu \mathrm{L}$ trizol untuk mencuci pinggiran tube, kocok dan vortex, kemudian diamkan 5 menit dalam suhu ruang. Tambahkan $200 \mu \mathrm{L}$ phenol-chloroform, kocok dengan tangan dan biarkan selama 5 menit. Sentrifugasi $13.000 \mathrm{rpm}$ selama 10 menit lapisan atas (supernatan) dibuang dapatkan pelet kemudian tambahkan $500 \mu \mathrm{L}$ isopropanol dan vortex. Simpan dalam suhu ruang selama 5 menit dan sentrifugasi 15.000 rpm selama 5 menit. Tambahkan $600 \mu \mathrm{L}$ ethanol $70 \%$, sentrifugasi $15.000 \mathrm{rpm}$ selama 5 menit kemudian supernatan dibuang, ambil peletnya dan dikering anginkan. Tambahkan $50 \mu \mathrm{L}$ dd $\mathrm{H}_{2} \mathrm{O}$ dikocok dengan tangan secara 
hati-hati dan inkubasi pada suhu $37^{\circ} \mathrm{C}$ selama 1-24 jam, genom siap digunakan untuk amplifikasi.

\section{Metode Ekstrasi dengan Lysis Buffer}

Sampel dicuci dari larutan preservasi (ethanol 90\%) dengan menggunakan $\mathrm{dd}_{2} \mathrm{O}$. Tambahkan $600 \mu \mathrm{L}$ Lysis buffer dan digerus kemudian tambahkan Proteinase K: $10 \mu \mathrm{L}$. Inkubasi dalam thermoblock pada suhu $65^{\circ} \mathrm{C}$ selama 30 menit. Setelah itu kocok dengan tangan dan diamkan 5 menit dalam suhu ruang, tambahkan $200 \mu \mathrm{L} 3 \mathrm{M} \mathrm{CH}_{3} \mathrm{COONA} \mathrm{pH-8} \mathrm{dan}$ kocok dengan tangan. Sentrifugasi $15.000 \mathrm{rpm}$ selama 5 menit kemudian supernatan (lapisan atas) diambil ( \pm ) $600 \mu \mathrm{L}$ dan tambahkan $600 \mu \mathrm{L}$ Isopropanol. Sentrifugasi 15.000 rpm selama 5 menit, buang supernatan, dan ambil peletnya kemudian tambahkan ethanol 70\%: $600 \mu \mathrm{L}$ kocok sampai terlarut. Sentrifugasi 15.000 rpm selama 2 menit, supernatan dibuang dan ambil peletnya kemudian diangin-anginkan. Tambahkan $50 \mu \mathrm{L} d d \mathrm{H}_{2} 0$ dan kocok dengan tangan perlahan dan genom DNA siap digunakan untuk amplifikasi.

\section{Amplifikasi Genome DNA dari Endoparasit}

Genom diamplifikasi menggunakan enzim polymerase dari Takara dan Qiagen taq DNA polymerase dengan menggunakan 2 set primer target yaitu P1 (1F x 1R) dan P2 (2F dan 2R). Spesifik primer ini didesain untuk mengidentifikasi Icthtyodinium chambelardi dari endoparasit pada ikan kerapu sunu (coral trout) Yuasa et al. (2006). Sequen primer yang dipergunakan adalah sebagai berikut: $\mathrm{Pl}: 96 \mathrm{f}$ (1F) ACTTGGCGGTTATTCTCTAC; 629 r (1R) GGACCAGCTA TITTCAGCAA dan P2: $1322 \mathrm{f}$ (2F)
CCGGAACTTTAGAGTATCGG; 1680r $(2 \mathrm{R})=$ TCGGTTCAGACTGA ACCAAG. Amplifikasi dilakukan menggunakan beberapa larutan pereaksi dengan total volume $25 \mu \mathrm{L}$ yang terdiri atas: double distillited $\mathrm{H}_{2} \mathrm{O}: 18.875 \mu \mathrm{L}$, 25 mM dNTP: $2 \mu \mathrm{L}$, buffer: $2,5 \mu \mathrm{L}$; taq DNA polymerase: 0,125 $\mu \mathrm{L}$; primer 1 (forward): 0,25 $\mu \mathrm{L}$; primer 2 (reverse): 0,25 $\mu \mathrm{L}$; template DNA: 1 $\mu \mathrm{L}$. Thermal cycler untuk amplifikasi DNA terlihat pada Tabel 1.

Hasil PCR dielektroforesis menggunakan $1.5 \%$ agarose gel (L.E. analytical grade) dalam $1 \times$ TAE buffer selama 30 menit. Sebagai molekuler marker digunakan DNA ladder 100 bp. Pewarnaan menggunakan ethidium bromide dan visualisasi dari cDNA menggunakan ultraviolet transilluminator kemudian didokumentasikan menggunakan gel kamera.

\section{HASIL DAN BAHASAN}

\section{Infeksi Endoparasit}

Yolk opaque syndrome merupakan suatu kejadian di mana endoparasit menginfeksi telur dan berkembang di dalamnya sehingga telur atau larva yang baru menetas menunjukkan warna keruh/buram (Pedersen, 1993). Infeksi parasit ini pertama kali diketahui di BBRPBL, Gondol-Bali terjadi pada tanggal 20 Oktober 2005. Persentase telur yang terinfeksi mencapai $100 \%$ yang artinya keseluruhan dari total telur semuanya terinfeksi. Selengkapnya terlihat pada Gambar 1 .

Telur yang terinfeksi dapat menetas menjadi larva namun 1 hari setelah menetas larva akan mati. Embrio dan larva yang terinfeksi oleh parasit dapat dilihat pada Gambar 2.

Tabel 1. Program thermal cycler amplifikasi PCR DNA endoparasit

Table 1. Thermal cycler program for PCR amplification of endoparasit

\begin{tabular}{lccc}
\hline \multicolumn{1}{c}{$\begin{array}{c}\text { Reaksi } \\
\text { Reaction }\end{array}$} & $\begin{array}{c}\text { Siklus } \\
\text { Cycle }\end{array}$ & $\begin{array}{c}\text { Suhu }\left({ }^{\circ} \mathrm{C}\right) \\
\text { Temperature }\end{array}$ & $\begin{array}{c}\text { Lama reaksi } \\
\text { Duration }\end{array}$ \\
\hline $\begin{array}{l}\text { Initial denaturation } \\
\text { Denaturation }\end{array}$ & 1 & 94 & 5 menit (minutes) \\
Annealing & 35 & 94 & 30 detik (second) \\
Extention & & 58 & 30 detik (second) \\
Final extention & 1 & 72 & 30 detik (second) \\
Preservation & & 72 & 5 menit (minutes) \\
\hline
\end{tabular}




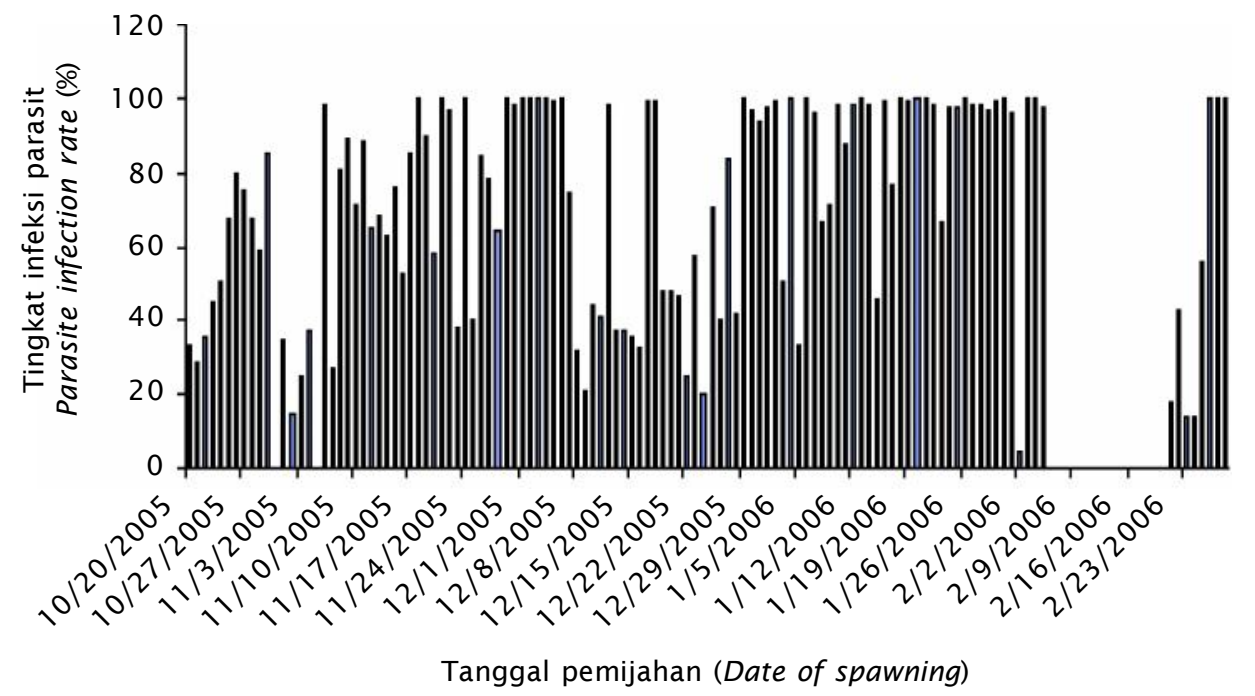

Gambar 1. Persentase telur ikan tuna sirip kuning, T. albacares yang terinfeksi endoparasit pada fase embrio

Figure 1. Percentages of infected egg of yellowfin tuna, T. albacares on embryo stage

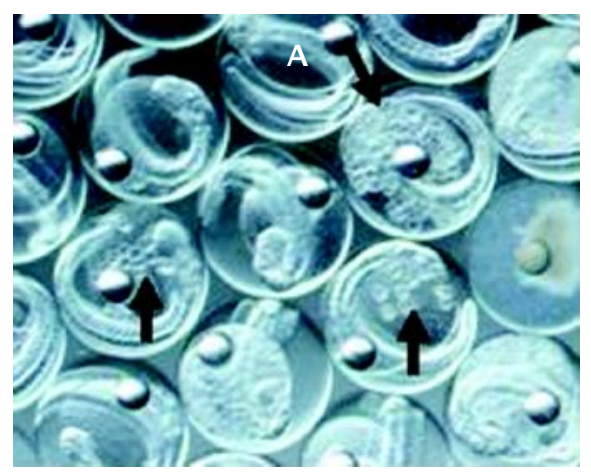

Telur yang terinfeksi sebelum menetas

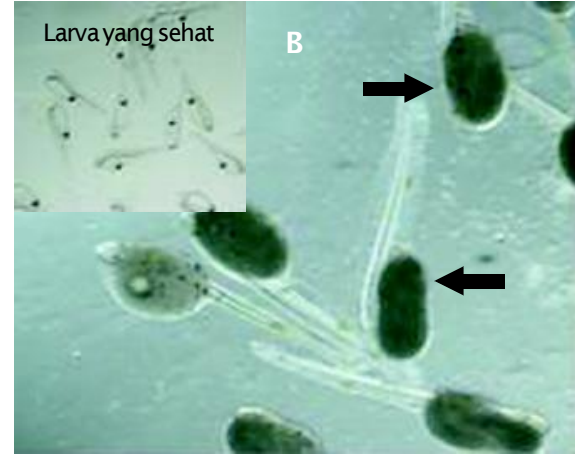

Larva terinfeksi hari ke-0

Gambar 2. Infeksi endoparasit (A) pada telur dan (B) larva d-0

Figure 2. Endoparasite infection $(A)$ on egg and $(B)$ larvae

\section{Deteksi Endoparasit dengan PCR}

Hasil deteksi endoparasit yang menginfeksi telur dan larva ikan tuna sirip kuning dengan menggunakan 2 metode ekstraksi tersaji pada Gambar 3.

Metode ekstraksi menggunakan lysis buffer memberikan resolusi pita yang lebih jelas dibandingkan dengan metode trizol. Pada metode ini penambahan Proteinase $K$ yang berfungsi untuk memecah protein mempunyai peranan yang cukup penting.
Amplifikasi dengan menggunakan 2 set primer yaitu primer set $\mathrm{P} 1$ dan $\mathrm{P} 2$ dapat dilihat pada (Gambar 4). Primer P2 yaitu (1322f $\mathrm{x}$ 1680r) menghasilkan pita yang konsisten dan lebih jelas dengan berat molekul 350 bp dan dapat mendeteksi endoparasit (Ichtyodinium chambelardii). Pola pita dari sampel telur dan larva yang digunakan untuk analisis menunjukkan hasil yang tidak terlalu berbeda artinya sampel untuk identifikasi endoparasit dapat menggunakan telur dan larva yang terinfeksi. 


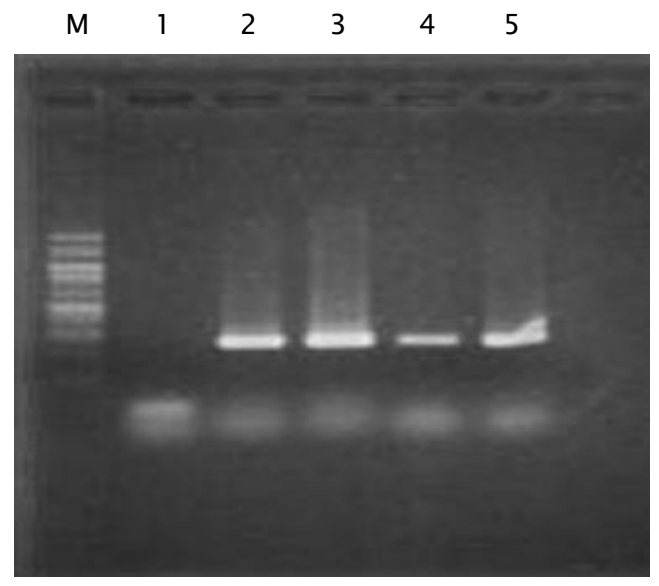

Gambar 3. Hasil amplifikasi PCR dari telur yang terinfeksi endoparasit dari telur dan larva ikan tuna sirip kuning ( $M=100$ bp DNA ladder; $1=$ negatif kontrol; $2-3$ = sampel yang diekstraksi dengan lysis buffer; 4-5 = sampel yang diekstraksi dengan trizol)

Figure 3. Result of PCR amplification from infected egg and larvae of yellowfin tuna ( $M=100$ bp DNA ladder; 1 = negatif control; $2-3=$ sample extracted by lysis buffer; 4-5 = sample extracted by trizol)

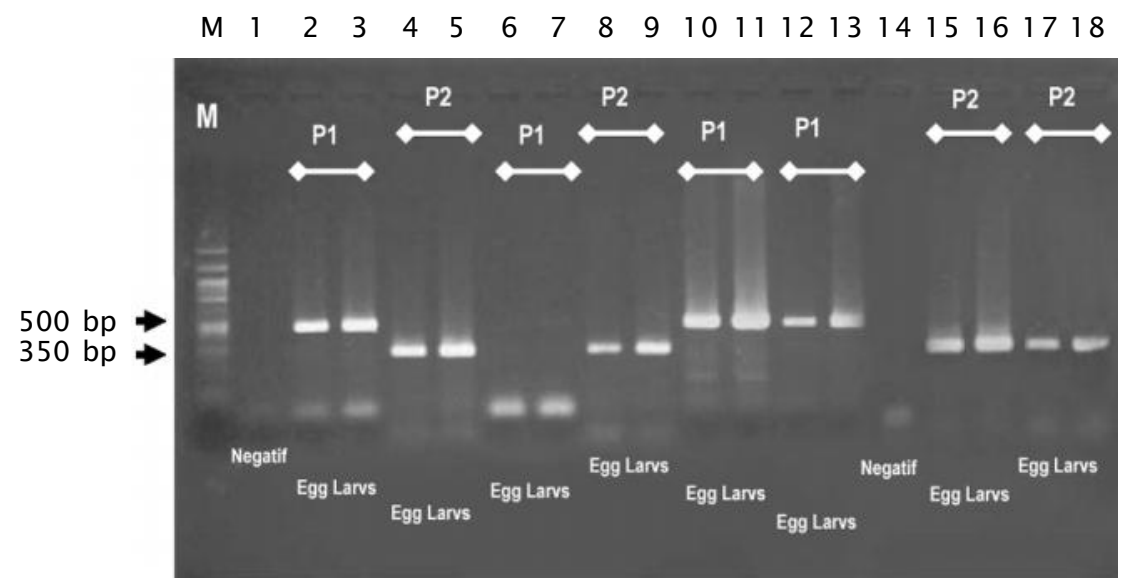

Gambar 4. Amplifikasi dengan PCR dari telur dan larva yang terinfeksi menggunakan 2 set primer ( $\mathrm{P} 1$ : primer 1 dan $\mathrm{P} 2$ : primer2), $\mathrm{M}=$ marker $100 \mathrm{bp}$, nomor $1 \& 14=$ negatif kontrol

Figure 4. Amplification of infected egg and larva by PCR using 2 sets of primer (P1: primer 1 and $P 2$ : primer 2 ), $M=$ marker $100 \mathrm{bp}$, lane $1 \& 14=$ negatif control

\section{Deteksi Endoparasit dari Gonad Induk, Pakan, dan Air Pemeliharaan}

Berdasarkan hasil PCR endoparasit ini tidak tampak pada gonad dan testis serta pada pakan dengan hasil negatif. Namun terdeteksi pada air pemeliharaan. Hasil PCR selengkapnya terlihat pada Gambar 5.

Beberapa penelitian dan pendapat menyatakan bahwa cara infeksi endoparasit ini secara vertikal (Hutapea et al., 2007; 


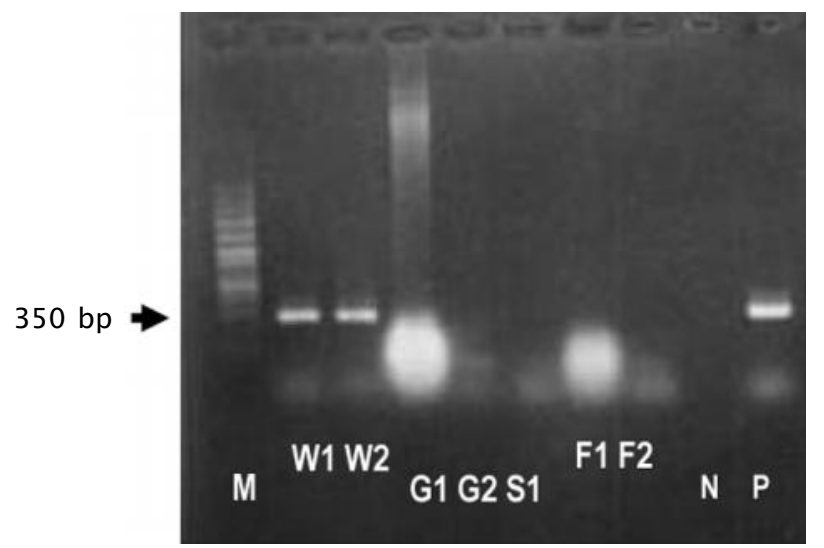

Gambar 5. Hasil amplifikasi endoparasit dari air pemeliharaan (W1,W2), gonad induk (G1,G2), sperma induk (S1) dan pakan tuna/ikan layang (F1 , F2), kontrol negatif (N), kontrol positif (P), dan marker $100 \mathrm{bp}(\mathrm{M})$

Figure 5. Electrophoresis of amplified products by PCR from rearing water (W1, W2), broodstock gonads (G1, G2), sperm (S1) and broodstock feed (F1, F2), negatif control (N), positif control (P), and marker $100 b p(M)$

Permana et al., 2007). Diduga bahwa telur yang terinfeksi telah terjadi sewaktu masih di dalam gonad. Namun fakta yang didapatkan dari penelitian ini terlihat bahwa gonad induk ikan tuna dan pakan ikan yang digunakan negatif atau tidak terinfeksi, tetapi pada air pemeliharaan positif terdapat endoparasit (Gambar 5). Hal ini mengindikasikan bahwa infeksi dari endoparasit ini adalah horisontal atau melalui air pemeliharaan. Air media pemeliharaan yang dipergunakan sebagai sampel sebanyak 200 liter air yang disaring dengan saringan $20 \mu$, tetapi hasil analisisnya terlihat positif dengan penampakan pita sangat jelas, dapat diduga bahwa populasinya cukup tinggi dalam bak pemeliharaan induk. Deteksi lebih lanjut dilakukan untuk melihat adanya sebaran endoparasit ini pada air laut langsung (fresh sea water) dan setelah melalui penyaringan dengan filter pasir/sand filter (Gambar 6).

Dari Gambar 6 terlihat bahwa endoparasit ini sudah terdapat di perairan (air laut langsung) meskipun dengan jumlah yang sangat terbatas. Sedangkan pada media air pemeliharaan induk ikan tuna sirip kuning yang menggunakan sistem resirkulasi $50 \%$ melalui filter pasir (sand filter) dan 50\% air laut langsung pada bak pemeliharaan induk masih dijumpai endoparasit dengan kepadatan cukup tinggi. Penyaringan air dengan filter pasir belum mampu menghilangkan endoparasit tetapi hanya menurunkan populasinya. Dari fenomena tersebut jelas terjawab bahwa infeksi endoparasit ini secara horisontal artinya telur-telur yang dikeluarkan oleh induk ikan tuna pada saat spawning tidak terinfeksi akan tetapi setelah kontak dengan air endoparasit ini dapat menginfeksi. Salah satu fakta yang memperkuat argumen ini adalah hasil observasi jumlah rata-rata telur yang terinfeksi yang dipanen 3 jam setelah memijah/spawning (30\%-80\%) lebih rendah dibandingkan dengan 12 jam setelah spawning (100\%).

\section{KESIMPULAN DAN SARAN}

Ekstraksi genom DNA dengan menggunakan metode lysis buffer dan primer set P2 (1322f x 1680r) memberikan hasil yang konsisten dan pita yang jelas untuk mendeteksi endoparasit Icthtyodinium chambelardi. Telur dan larva terinfeksi endoparasi secara horisontal atau dari air pemeliharaan.

Untuk menghindari infeksi yang tinggi dapat dilakukan pemanenan telur paling lambat 30 menit setelah spawning dan atau melakukan treatment air. 


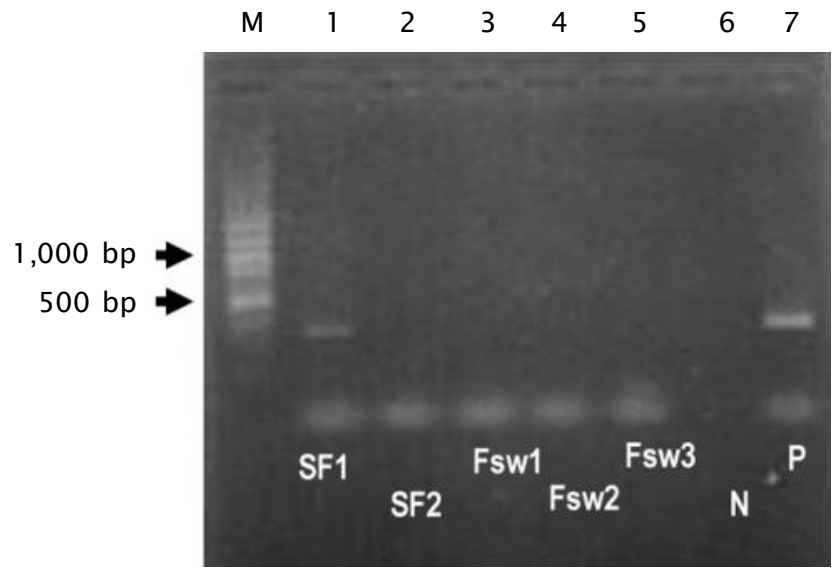

Gambar 6. Amplifikasi PCR endoparasit yang terdapat pada filter pasir dan air laut langsung $(\mathrm{SF} 1=$ sand filter $400 \mathrm{~L}, \mathrm{SF} 2=$ sand filter 200L, Fsw1 = fresh sea water $100 \mathrm{~L}, \mathrm{Fsw} 2=$ fresh sea water $200 \mathrm{~L}, \mathrm{Fsw} 3=$ fresh sea water $300 \mathrm{~L}, \mathrm{~N}=$ negatif kontrol, dan $\mathrm{P}=$ positif kontrol)

Figure 6. PCR amplification of endoparasite collected from sand filter and fresh sea water (SF1 = sand filter 400L, SF2 = sand filter $200 \mathrm{~L}$, Fsw 1 = fresh sea water $100 \mathrm{~L}$, Fsw2 = fresh sea water $200 \mathrm{~L}, \mathrm{Fsw} 3$ = fresh sea water $300 \mathrm{~L}, \mathrm{~N}=$ negatif control, and $P=$ positif control)

\section{UCAPAN TERIMA KASIH}

Riset ini dapat terlaksana atas kerja sama BBRPBL-Gondol, Bali dengan OFCF-Japan. Penulis mengucapkan terima kasih kepada Mr. Akio Nakazawa sebagai chief expert dan Mr. Kei Yuasa sebagai shorterm expert patologi dari Overseas Fishery Cooperation Foundation (OFCF) Jepang dan seluruh staf teknisi bioteknologi BBRPBL-Gondol dan Teknisi tuna atas segala bantuan selama penelitian ini dilakukan.

\section{DAFTAR ACUAN}

Collate, B.B. \& Nauen, C.E. 1983. FAO Fish cataloque. Vol. 2. Scombrids of the world. An annotated and illustrated cataloque of tunas, mackerels, bonitos and related species known to date. FAO Fish Synop., (125) 2: 1-137.

Hollande, A. \& Cachon, J. 1952. Un parasites des oeuf de sardine: Ichtyodinium chambelardinov. gen. nov. sp. (Peridinien parasite). C.R. Acad. Sci., 3(235): 976-977.

Hutapea, J.H. \& Permana, G.N. 2007. Siklus Hidup Endoparasit, Ichtyodinium chabelardi, yang Menginfeksi Telur Ikan Laut. Prosiding
Seminar Nasional Kelautan III Universitas Hang Tuah Surabaya 24 April 2007, hlm. 68-72.

Ishimaru, K. 2004. Yolk Opaque Symptom of ferlilized egg and hatchout larvae of Bluefin tuna. In Japanes, p. 43-45. Ishimaru@cypress.ne.jp. Diakses tanggal 15 Januari 2007.

Ishimaru, K. 2005. The 21 st-century COE program of Kinki University. The supportivetype research base of the fish culture industry of bluefin tuna and others. The cause of yolk nebula disease observed in the fertilized eggs and hatched fingerlings of bluefin tuna Kinki University. Center of Aquaculture Science and Technology for Bluefin Tuna and Other Cultivated Fish. 21 st Century COE Program, 2: 43-45.

Pedersen, B.H. 1993. Embryos and yolk-sac larvae of turbot, Scopthalmus maximus are infested with an endoparasite from gastrulla stage onwards. Dis. Aquat. Org., 17: 57-59.

Pedersen, B.H., Buchmann, K., \& Koie, M. 1994. Baltic larval cod, Gadus morhua are infected with a protistan endoparasit in the yolk sac. Dis. Aquat. Org., 16: 29-33. 
Permana, G.N., Hutapea, J.H., \& Sugama, K. 2007. Yolk opaque syndrome pada telur ikan tuna sirip kuning (Thunnus albacares). Media akuakultur, 2(1): 137-141.

Yuasa, K., Nakazawa, A., Hutapea, J.H., Permana, G.N., Haryanti, Zafran, Rosa, D., \& Rafael,

F.J. 2006. A trial to establish control measures for the infection with protistan endoparasite causing 'yolk sac opaque syndrome of yellowfin tuna'. A Techical Report of OFCF Fish Disease Expert, 8 pp. 